\title{
Associations between the severity of reflux esophagitis in children and changes in oxidative stress, serum inflammation, vasoactive intestinal peptide and motilin
}

\author{
YINGQIN DENG, LI PAN and WENJIE QIAN \\ Department of Pediatrics, Changzhou Jintan District People's Hospital, Changzhou, Jiangsu 213200, P.R. China
}

Received April 17, 2019; Accepted June 13, 2019

DOI: $10.3892 /$ etm.2019.7978

\begin{abstract}
Changes in the levels of serum oxidative stress indexes, gastrointestinal hormones and inflammatory factors in children with different severity of reflux esophagitis (RE) were detected. Sixty child patients diagnosed with gastroesophageal reflux disease (GERD) via gastroscopy were selected and divided into non-erosive reflux disease group (NERD group, $n=12)$ and RE group $(n=48)$ according to whether there was esophageal mucosal injury. In RE group, the patients were further divided into grade I RE group $(n=15)$, grade II RE group $(n=18)$ and grade III RE group $(n=15)$ based on the severity of mucosal injury. None of the child patients took PPI and domperidone within 2 weeks before enrollment. The content of malondialdehyde (MDA) and total superoxide dismutase (T-SOD) in the esophageal mucosa was detected. The changes in the levels of serum vasoactive intestinal peptide (VIP), motilin, interleukin-1 $\beta$ (IL-1 $\beta$ ), IL-8 and tumor necrosis factor- $\alpha$ (TNF- $\alpha$ ) were determined. The DeMeester score was the highest in grade III RE group, followed by grade II RE group, grade I RE group and NERD group $(\mathrm{P}<0.05)$. The content of MDA in the esophageal mucosa was higher in RE group than that in NERD group, and the T-SOD activity declined with the increased severity of injury $(\mathrm{P}<0.05)$. In the three $\mathrm{RE}$ groups, the level of plasma VIP was significantly higher, while the motilin level was remarkably lower than those in NERD group $(\mathrm{P}<0.05)$. With the increased severity of disease, the expression levels of serum IL- $1 \beta$, IL- 8 and TNF- $\alpha$ in RE group were gradually raised $(\mathrm{P}<0.05)$. $\mathrm{RE}$ patients have strong oxidative stress and inflammatory response, an increased level of serum VIP, a regulator of gastrointestinal motility, and a decreased level of motilin. Controlling the changes in the above factors using effective treatment means can improve the development of GERD.
\end{abstract}

Correspondence to: Dr Wenjie Qian, Department of Pediatrics, Changzhou Jintan District People's Hospital, 16 Nanmen Avenue, Changzhou, Jiangsu 213200, P.R. China

E-mail: boyo406@126.com

Key words: children, reflux esophagitis, oxidative stress, serum inflammation, vasoactive intestinal peptide, gastric dynamic element

\section{Introduction}

Gastroesophageal reflux disease (GERD) in children has attracted increasingly more attention from clinicians due to its high morbidity rate and serious influence on the quality of life of child patients $(1,2)$. Reflux esophagitis (RE) can be diagnosed when the abnormalities in the esophageal mucosa are detected in gastroscopy. Inflammatory mediators and other factors can destroy the esophageal mucosal barrier, reduce the lower esophageal sphincter pressure (LESP) and lower the esophageal peristalsis, ultimately leading to $\operatorname{RE}(3,4)$. The role of oxidative stress in esophageal mucosal injury is gradually receiving increased attention. Excessive reactive oxygen species (ROS) are produced by mucosal epithelial cells under stress due to the reflux of gastric contents, causing mucosal damage (5). The present study detected the changes in the levels of serum malondialdehyde (MDA), total superoxide dismutase (T-SOD), vasoactive intestinal peptide (VIP), motilin, interleukin-1 $\beta$ (IL-1 $\beta$ ), IL-8 and tumor necrosis factor- $\alpha(\mathrm{TNF}-\alpha)$ in child patients with different severity of $\mathrm{RE}$, evaluated their associations with the severity of disease and explored their clinical significance.

\section{Patients and methods}

Clinical data. A total of 60 child patients (aged 7 months to 16 years) with such upper digestive tract symptoms such as vomiting, acid reflux and heartburn and diagnosed with GERD via gastroscopy and mucosal pathological changes in Changzhou Jintan District People's Hospital (Changzhou, China) from March 2018 to December 2018 were selected as the objects of study. Among them, there were 39 boys and 21 girls, 5 cases were younger than 1 year of age, 20 cases were aged 1 to 3 years, 10 cases were aged 3 to 6 years, 6 cases were aged 6 to 9 years, 11 cases were aged 9 to 12 years, and 8 cases were aged 12 to 16 years. None of them took PPI and domperidone within 2 weeks before enrollment and they all had good compliance. The patients were divided into non-erosive reflux disease group (NERD group, $n=12$ ) and (RE group $n=48$ ) according to whether there was esophageal mucosal injury. In RE group, the patients were further divided into grade I RE group ( $\mathrm{n}=15)$, grade II RE group $(n=18)$ and grade III RE group $(n=15)$ based on the severity of mucosal injury. The sex and age were comparable in each group $(\mathrm{P}>0.05)$. This study was explained to the family 
Table I. Changes in oxidative stress indexes in RE groups and NERD group (mean $\pm \mathrm{SD})$.

\begin{tabular}{lcccc}
\hline Index & $\begin{array}{c}\text { NERD group } \\
(\mathrm{n}=12)\end{array}$ & $\begin{array}{c}\text { Grade I RE group } \\
(\mathrm{n}=15)\end{array}$ & $\begin{array}{c}\text { Grade II RE group } \\
(\mathrm{n}=18)\end{array}$ & $\begin{array}{c}\text { Grade III RE group } \\
(\mathrm{n}=15)\end{array}$ \\
\hline MDA content (nmol/g prot) & $8.1 \pm 3.6$ & $12.3 \pm 4.9$ & $21.2 \pm 6.7^{\mathrm{a}, \mathrm{b}}$ & $35.5 \pm 5.7^{\mathrm{a}-\mathrm{c}}$ \\
T-SOD activity (U/mg prot) & $56 \pm 21$ & $41 \pm 14^{\mathrm{a}}$ & $30 \pm 15^{\mathrm{a}, \mathrm{b}}$ & $19 \pm 9^{\mathrm{a}-\mathrm{c}}$ \\
\hline
\end{tabular}

${ }^{\mathrm{a}} \mathrm{P}<0.05$ vs. NERD group, ${ }^{\mathrm{b}} \mathrm{P}<0.05$ vs. grade I RE group, ${ }^{\mathrm{c}} \mathrm{P}<0.05$ vs. grade II RE group. RE, reflux esophagitis; NERD, non-erosive reflux disease; MDA, malondialdehyde; T-SOD, total superoxide dismutase; prot, protein.

members of the patients and approved by the Ethics Committee of Changzhou Jintan District People's Hospital. Informed consents were signed by the child parents or guardians.

Research methods. After admission, the examinations were performed, and the body weight was controlled through lowsugar and low-fat diet. After the serum and esophageal mucosa specimens were collected, the patients were treated with drugs (proton pump inhibitor, mucosal protective agent and gastrointestinal prokinetic agent) or underwent operation according to the severity of disease.

\section{Detection indexes}

Detection of serum VIP, motilin, IL-1 $\beta, I L-8$ and TNF- $\alpha$ levels. The serum IL-1 $\beta$, IL- 8 and TNF- $\alpha$ levels were measured using the Multiskan Sky microplate reader (Thermo Fisher Scientific, Inc.), and the VIP and motilin levels were measured using the UniCelDxI 600 full-automatic immunoassay analyzer (Beckman Coulter, Inc.).

Monitoring of 24 h esophageal pH indexes. The DeMeester score, longest time of reflux, severe acid exposure ratio and total times of reflux were determined.

LESP. LESP was measured using the XDJ-S8 upper digestive tract dynamic monitoring system (Anhui Kaili Science \& Technology group Co., Ltd.).

Lower esophageal mucosa. The lower esophageal mucosa was collected under the EG-600WR electronic gastroscope (Fuji), and prepared into mucosal homogenate to determine the MDA using thiobarbituric acid (TBA) assay and T-SOD using hydroxylamine assay.

Correlation. The correlation between each index and DeMeester score was analyzed.

Statistical analysis. SPSS 20.0 software (IBM) was used for statistical analysis. The measurement data were expressed as mean \pm standard deviation, one-way analysis of variance was performed for the comparison among multiple groups, and LSD test was adopted as a post hoc test for the comparison between two groups. The enumeration data were expressed as rate $(\%)$, and $\chi^{2}$ test was performed. Pearson's correlation analysis was used for the correlation. $\mathrm{P}<0.05$ was considered to indicate a statistically significant difference.

\section{Results}

Changes in oxidative stress indexes. The results showed that the content of MDA was 8.1 $\pm 3.6,12.3 \pm 4.9,21.2 \pm 6.7$ and
Table II. Comparison of levels of serum inflammatory factors between RE group and NERD group (mean $\pm \mathrm{SD}, \mathrm{pg} / \mathrm{ml}$ ).

\begin{tabular}{lcccc}
\hline Group & $\mathrm{n}$ & IL-1 $\beta$ & \multicolumn{1}{c}{ IL-8 } & TNF- $\alpha$ \\
\hline NERD & 12 & $26.8 \pm 3.7$ & $18.6 \pm 3.3$ & $30.4 \pm 4.2$ \\
Grade I RE & 15 & $42.5 \pm 8.2^{\mathrm{a}}$ & $37.5 \pm 4.5^{\mathrm{a}}$ & $44.6 \pm 5.7^{\mathrm{a}}$ \\
Grade II RE & 18 & $54.8 \pm 7.2^{\mathrm{a}, \mathrm{b}}$ & $46.7 \pm 5.5^{\mathrm{a}, \mathrm{b}}$ & $57.4 \pm 5.6^{\mathrm{a}, \mathrm{b}}$ \\
Grade III RE & 15 & $65.6 \pm 8.3^{\mathrm{a}, \mathrm{b}}$ & $72.2 \pm 6.1^{\mathrm{a}-\mathrm{c}}$ & $63.2 \pm 6.3^{\mathrm{a}, \mathrm{b}}$ \\
\hline
\end{tabular}

${ }^{\mathrm{a}} \mathrm{P}<0.05$ vs. NERD group, ${ }^{\mathrm{b}} \mathrm{P}<0.05$ vs. grade I RE group, ${ }^{\mathrm{c}} \mathrm{P}<0.05$ vs. grade II RE group. RE, reflux esophagitis; NERD, non-erosive reflux disease; IL-1 $\beta$, interleukin-1 $\beta$; IL-8, interleukin-8; TNF- $\alpha$, tumor necrosis factor- $\alpha$.

Table III. LESP, VIP and motilin levels in RE group and NERD group (mean $\pm \mathrm{SD})$.

\begin{tabular}{lcccc}
\hline Group & $\mathrm{n}$ & $\begin{array}{c}\text { LESP } \\
(\mathrm{mmHg})\end{array}$ & $\begin{array}{c}\text { VIP } \\
(\mathrm{pg} / \mathrm{l})\end{array}$ & $\begin{array}{c}\text { Motilin } \\
(\mathrm{ng} / \mathrm{l})\end{array}$ \\
\hline NERD & 12 & $23.55 \pm 4.53$ & $15.2 \pm 3.92$ & $298.26 \pm 89.11$ \\
Grade I RE & 15 & $15.32 \pm 5.01^{\mathrm{a}}$ & $21.4 \pm 5.12^{\mathrm{a}}$ & $245.22 \pm 80.49^{\mathrm{a}}$ \\
Grade II RE & 18 & $11.21 \pm 4.56^{\mathrm{a}}$ & $29.2 \pm 5.32^{\mathrm{a}, \mathrm{b}}$ & $215.07 \pm 78.45^{\mathrm{a}}$ \\
Grade III RE & 15 & $5.43 \pm 5.24^{\mathrm{a}}$ & $37.8 \pm 7.23^{\mathrm{a}-\mathrm{c}}$ & $171.32 \pm 45.60^{\mathrm{a}}$
\end{tabular}

${ }^{\mathrm{a}} \mathrm{P}<0.05$ vs. NERD group, ${ }^{\mathrm{b}} \mathrm{P}<0.05$ vs. grade I RE group, ${ }^{\mathrm{c}} \mathrm{P}<0.05$ vs. grade II RE group. LESP, lower esophageal sphincter pressure; VIP, vasoactive intestinal peptide; RE, reflux esophagitis; NERD, non-erosive reflux disease.

$35.5 \pm 5.7 \mathrm{nmol} / \mathrm{g}$ protein in NERD, grade I RE, grade II RE and grade III RE group, respectively, and the T-SOD activity was $56 \pm 21,41 \pm 14,30 \pm 15$ and $19 \pm 9 \mathrm{U} / \mathrm{mg}$ protein in the four groups, respectively, displaying statistically significant differences $(\mathrm{P}<0.05)$. The above findings indicate that the levels of oxidative stress indexes are related to the degree of mucosal injury (Table I).

Changes in levels of serum inflammatory factors. With the aggravation of disease, the expression levels of serum IL-1 $\beta$, IL-8 and TNF- $\alpha$ in RE group were gradually increased. The levels of inflammatory factors had statistically significant differences between RE group and NERD group and among the three RE groups $(\mathrm{P}<0.05)$. 
Table IV. Changes in $24 \mathrm{~h}$ esophageal $\mathrm{pH}$ indexes in RE group and NERD group.

\begin{tabular}{|c|c|c|c|c|c|}
\hline Group & $\mathrm{n}$ & $\begin{array}{l}\text { DeMeester score } \\
\text { (points) }\end{array}$ & $\begin{array}{l}\text { Longest time of } \\
\text { reflux }(\mathrm{min})\end{array}$ & $\begin{array}{l}\text { Severe acid exposure } \\
\text { ratio }[\mathrm{n}(\%)]\end{array}$ & $\begin{array}{l}\text { Total times } \\
\text { of reflux }\end{array}$ \\
\hline NERD & 12 & $42.3 \pm 9.9$ & $15.9 \pm 4.9$ & $2(16.6)$ & $2.38 \pm 1.17$ \\
\hline Grade I RE & 15 & $44.9 \pm 9.1$ & $20.2 \pm 6.1$ & $3(20.0)$ & $3.22 \pm 1.49$ \\
\hline Grade II RE & 18 & $58.6 \pm 10.2^{\mathrm{a}}$ & $24.6 \pm 5.5^{\mathrm{a}}$ & $5(27.7)$ & $4.38 \pm 1.55^{\mathrm{a}}$ \\
\hline Grade III RE & 15 & $70.7 \pm 12.5^{\mathrm{a}, \mathrm{b}}$ & $33.5 \pm 7.2^{\mathrm{a}, \mathrm{b}}$ & $8(53.3)^{\mathrm{a}, \mathrm{b}}$ & $6.12 \pm 1.67^{\mathrm{a}, \mathrm{b}}$ \\
\hline
\end{tabular}

${ }^{\mathrm{a}} \mathrm{P}<0.05$ vs. NERD group, ${ }^{\mathrm{b}} \mathrm{P}<0.05$ vs. grade II RE group. RE, reflux esophagitis; NERD, non-erosive reflux disease.

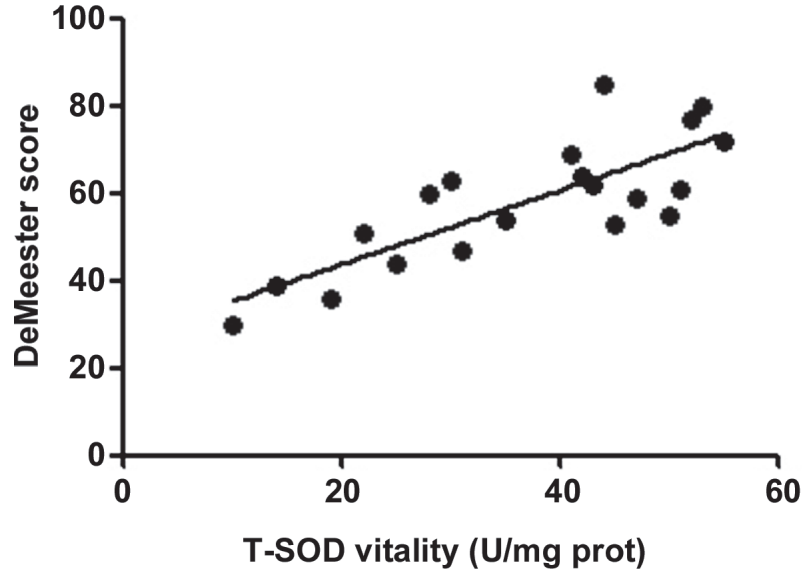

Figure 1. Correlation between T-SOD and DeMeester score $(r=0.6376)$. T-SOD, total superoxide dismutase; prot, protein.

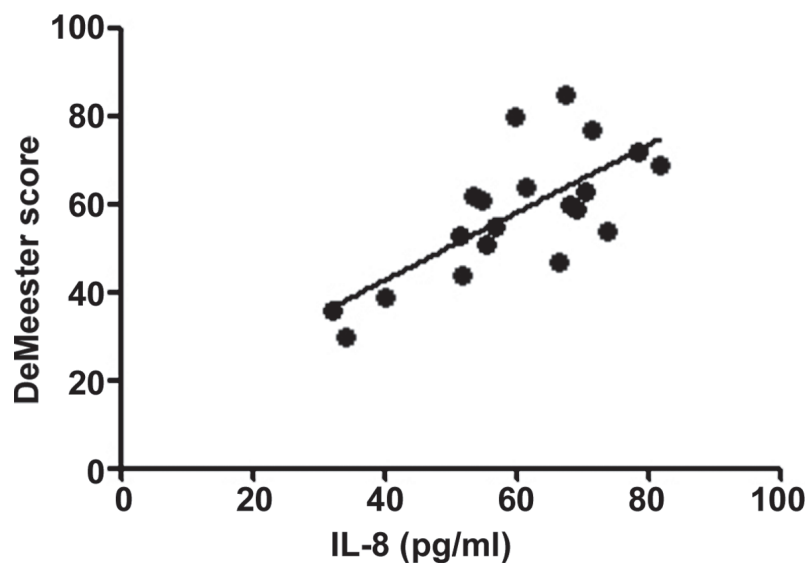

Figure 2. Correlation between IL-8 and DeMeester score ( $\mathrm{r}=0.5241)$. IL-8, interleukin-8.

The levels of serum inflammatory factors were gradually elevated in patients with different severity of RE, which were significantly higher than those in NERD group. Besides, the more severe the mucosal injury was, the higher the levels of inflammatory factors would be $(\mathrm{P}<0.05)$ (Table II).

Changes in levels of VIP, motilin and LESP. The results revealed that the VIP level was $15.2 \pm 3.92,21.4 \pm 5.12$, $29.2 \pm 5.32$ and $37.8 \pm 7.23 \mathrm{pg} / \mathrm{l}$ in NERD, grade I RE, grade II

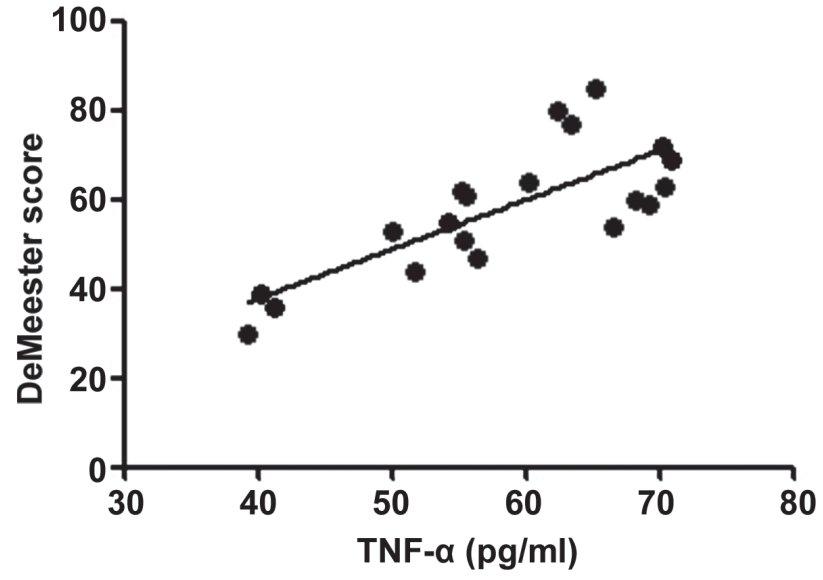

Figure 3. Correlation between TNF- $\alpha$ and DeMeester score $(r=0.5958)$. TNF- $\alpha$, tumor necrosis factor- $\alpha$.

RE and grade III RE group, respectively, and the level of motilin was $298.26 \pm 89.11,245.22 \pm 80.49,215.07 \pm 78.45$ and $171.32 \pm 45.60 \mathrm{ng} / \mathrm{l}$ in the four groups, respectively. Thus, the results show that with the increase in severity of disease, the VIP level was gradually increased and the level of motilin was gradually decreased in RE group. The levels of VIP, motilin and LESP had statistically significant differences between RE group and NERD group and the levels of VIP had statistically significant differences among the three RE groups $(\mathrm{P}<0.05)$ (Table III).

Changes in 24 h esophageal $p H$ indexes. The results mani-

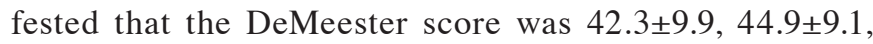
$58.6 \pm 10.2$ and $70.7 \pm 12.5$ points in NERD, grade I RE, grade II $\mathrm{RE}$ and grade III RE group, respectively, suggesting that the more severe injury corresponds to the higher DeMeester score. The DeMeester score had statistically significant differences in grade II RE group and grade III RE group compared with NERD group, and between grade II RE group and grade III RE group $(\mathrm{P}<0.05)$. Besides, the longest time of reflux, severe acid exposure ratio and total times of reflux in RE group were greater than those in NERD group $(\mathrm{P}<0.05)$ (Table IV).

Correlation of DeMeester score with inflammatory factors and motilin. According to the correlation analysis, the serum T-SOD, IL-8, TNF- $\alpha$ and VIP levels in RE patients were positively correlated with the DeMeester score $(r=0.6376,0.5241$, 0.5958 and $0.6118, \mathrm{P}<0.01$ ), confirming that the abnormal 


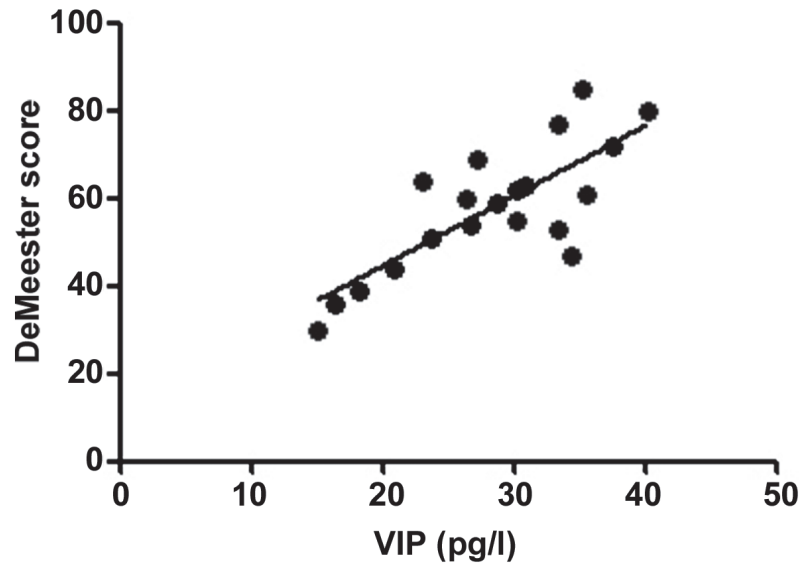

Figure 4. Correlation between VIP and DeMeester score ( $r=0.6118)$. VIP, vasoactive intestinal peptide.

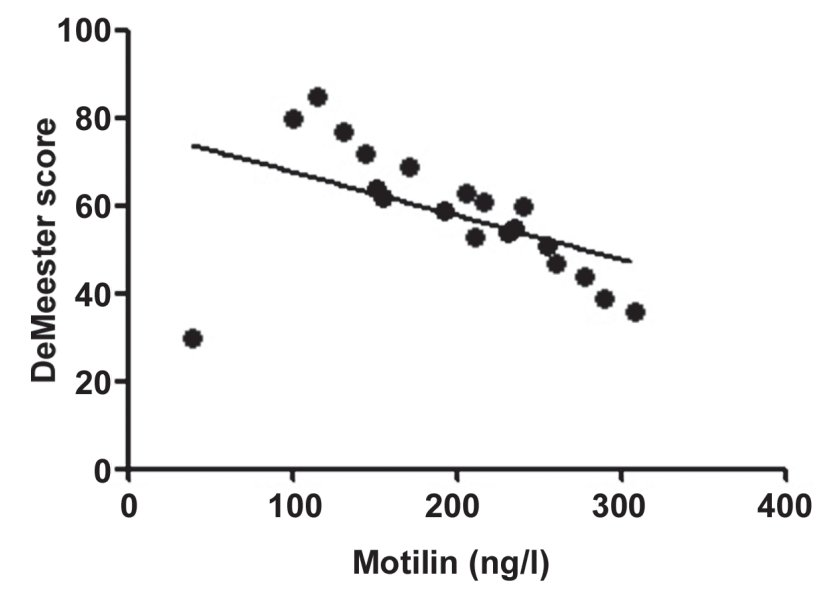

Figure 5. Correlation between motilin and DeMeester score $(r=-0.2283)$

expression levels of inflammatory factors in vivo are important factors leading to progression of RE. The more severe the disease was, the stronger the inflammatory response state in vivo would be. Moreover, the motilin level in RE patients was negatively correlated with the DeMeester score $(r=-0.2283$, $\mathrm{P}<0.05$ ), indicating that the abnormal expression of gastrointestinal hormones is also an important factor causing upper gastrointestinal motility disorders in RE (Figs. 1-5).

\section{Discussion}

$\mathrm{RE}$ is an upper gastrointestinal motility disorder, whose common clinical symptom is gastrointestinal dysfunction. RE is mainly diagnosed using gastroscopy and esophageal $\mathrm{pH}$ value. In recent years, a large number of studies have focused on the etiology and pathogenesis of RE, and scholars have found that the occurrence of esophageal mucosal injury and extraoesophageal complications in RE patients are closely associated with ILs and oxidative stress factors (6-8).

In the present study, the detection results of $24 \mathrm{~h}$ esophageal $\mathrm{pH}$ indexes showed that the DeMeester score was $42.3 \pm 9.9,44.9 \pm 9.1,58.6 \pm 10.2$ and $70.7 \pm 12.5$ points in NERD, grade I RE, grade II RE and grade III RE group, respectively, suggesting that the more severe injury corresponds to the higher DeMeester score. The DeMeester score had statistically significant differences in grade II RE group and grade III RE group compared with NERD group, and between grade II RE group and grade III RE group $(\mathrm{P}<0.05)$.

In the pathogenesis of GERD, ROS plays a crucial role, which can alter the normal function of enzymes and proteins (9). The results of this study revealed that the content of MDA was $8.1 \pm 3.6,12.3 \pm 4.9,21.2 \pm 6.7$ and $35.5 \pm 5.7 \mathrm{nmol} / \mathrm{g}$ protein in NERD, grade I RE, grade II RE and grade III RE group, respectively, and the T-SOD activity was $56 \pm 21,41 \pm 14,30 \pm 15$ and $19 \pm 9 \mathrm{U} / \mathrm{mg}$ protein, respectively, in the four groups, displaying statistically significant differences $(\mathrm{P}<0.05)$. It can be seen that the content of MDA in the esophageal mucosa was higher in RE group than that in NERD group, and the T-SOD activity declined with the increased severity of injury $(\mathrm{P}<0.05)$, indicating that the levels of oxidative stress indexes are related to the degree of mucosal injury.

Gastric acid and pepsin in RE patients can stimulate immune cells to release a variety of inflammatory mediators, directly damaging the esophageal mucosal epithelial cells (10). Previously, it was reported that the expression levels of IL-1 $\beta$ and IL-8 in the esophageal mucosa in RE patients are increased, and the degree of mucosal injury is positively correlated with the IL-8 level $(11,12)$. After effective drug or operative treatment, the IL-8 expression level in the esophageal mucosa declines, and it is found in the subsequent monitoring that the IL-8 level continuously increases in recurrence patients (13). TNF- $\alpha$ produced by macrophages and immune cells stimulates neutrophils to produce large amounts of ROS, leading to peroxidation of the esophageal mucosa (14). Moreover, studies have found that the increased levels of inflammatory factors are important factors leading to esophageal peristalsis disorder (15), and TNF- $\alpha$ can also promote the development of RE into Barrett's esophagitis to some extent (16). In the present study, the levels of serum IL- $1 \beta$, IL-8 and TNF- $\alpha$ were the highest in grade III RE group, followed by grade II RE group, grade I RE group and NERD group $(\mathrm{P}<0.05)$. According to the Pearson's correlation analysis, the serum T-SOD, IL-8 and TNF- $\alpha$ were positively correlated with the DeMeester score $(\mathrm{r}=0.6376,0.5241$ and $0.5958, \mathrm{P}<0.01)$, confirming that the abnormal expression levels of inflammatory factors in vivo are important leading to the progression of RE. The severer the disease is, the stronger the inflammatory response state in vivo will be.

VIP is a polypeptide with 28 amino acids in the gastrointestinal tract, which can regulate the esophageal peristalsis and esophageal sphincter relaxation under normal conditions (17). Upon the stimuli of pathological factors, VIP in vivo has an elevated level and binds to a large number of gastrointestinal epithelial cell receptors, reducing LESP and leading to GRED (18). The main role of motilin, another type of gastrointestinal hormone secreted by the duodenal and jejunal mucosa, is to affect the interdigestive gastrointestinal motility. According to previous clinical studies, the serum motilin level in patients with gastric motility disorder is lower than that in the normal people (19). In this experiment, the VIP level was $15.2 \pm 3.92,21.4 \pm 5.12,29.2 \pm 5.32$ and $37.8 \pm 7.23 \mathrm{pg} / \mathrm{l}$ in NERD, grade I RE, grade II RE and grade III RE group, respectively, and the level of motilin was $298.26 \pm 89.11,245.22 \pm 80.49$, $215.07 \pm 78.45$ and $171.32 \pm 45.60 \mathrm{ng} / \mathrm{l}$, respectively, in the 
four groups. It can be seen that in the three RE groups, the plasma VIP level was obviously higher than that in NERD group, while the motilin level was evidently lower than that in NERD group $(\mathrm{P}<0.05)$. The positive correlation between motilin level and LESP has been previously confirmed (20). In addition, the Pearson's correlation analysis showed that the motilin level in RE patients was negatively correlated with the DeMeester score $(r=-0.2283, \mathrm{P}<0.05)$, indicating that the abnormal expression of gastrointestinal hormones is also an important factor causing upper gastrointestinal motility disorders in RE.

In conclusion, RE patients have strong oxidative stress and inflammatory response, an increased level of serum regulator of gastrointestinal motility (VIP) and a decreased level of motilin, and the expression levels of these indexes are associated with the severity of RE. Controlling the changes in the above factors using effective treatment means can improve the development of GERD.

\section{Acknowledgements}

Not applicable.

\section{Funding}

No funding was received.

\section{Availability of data and materials}

The datasets used and/or analyzed during the current study are available from the corresponding author on reasonable request.

\section{Authors' contributions}

YD wrote the manuscript. YD and LP collected and analyzed general data of patients. WQ helped with indexes detection and analysis. All the authors read and approved the final manuscript.

\section{Ethics approval and consent to participate}

The study was approved by the Ethics Committee of Changzhou Jintan District People's Hospital (Changzhou, China) and informed consents were signed by the child parents or guardians.

\section{Patient consent for publication}

Not applicable.

\section{Competing interests}

The authors declare that they have no competing interests.

\section{References}

1. Moore M, Afaneh C, Benhuri D, Antonacci C, Abelson J and Zarnegar R: Gastroesophageal reflux disease: A review of surgical decision making. World J Gastrointest Surg 8: 77-83, 2016.
2. Altomare A, Guarino MP, Cocca S, Emerenziani S and Cicala M: Gastroesophageal reflux disease: Update on inflammation and symptom perception. World J Gastroenterol 19: 6523-6528, 2013.

3. di Pietro M, Alzoubaidi D and Fitzgerald RC: Barrett's esophagus and cancer risk: How research advances can impact clinical practice. Gut Liver 8: 356-370, 2014.

4. Hampel H, Abraham NS and El-Serag HB: Meta-analysis: Obesity and the risk for gastroesophageal reflux disease and its complications. Ann Intern Med 143: 199-211, 2005.

5. Giri AK, Rawat JK, Singh M, Gautam S and Kaithwas G: Effect of lycopene against gastroesophageal reflux disease in experimental animals. BMC Complement Altern Med 15: 110, 2015.

6. Tsai J, Blinman TA, Collins JL, Laje P, Hedrick HL, Adzick NS and Flake AW: The contribution of hiatal hernia to severe gastroesophageal reflux disease in patients with gastroschisis. J Pediatr Surg 49: 395-398, 2014.

7. Cao W, Liu Y,Zhang R, Zhang B, Wang T, Zhu X, Mei L, Chen H, Zhang H, Ming P, et al: Homoharringtonine induces apoptosis and inhibits STAT3 via IL-6/JAK1/STAT3 signal pathway in Gefitinib-resistant lung cancer cells. Sci Rep 5: 8477, 2015.

8. Abdel-Aziz H, Zaki HF, Neuhuber W, Kelber O, Weiser D and Khayyal MT: Effect of an herbal preparation, STW 5, in an acute model of reflux oesophagitis in rats. J Pharmacol Sci 113: 134-142, 2010.

9. Li D and Cao W: Role of intracellular calcium and NADPH oxidase NOX5-S in acid-induced DNA damage in Barrett's cells and Barrett's esophageal adenocarcinoma cells. Am J Physiol Gastrointest Liver Physiol 306: G863-G872, 2014.

10. Canning BJ and Mazzone SB: Reflex mechanisms in gastroesophageal reflux disease and asthma. Am J Med 115 (Suppl 3A): S45-S48, 2003

11. Huo X, Zhang X, Yu C, Zhang Q, Cheng E, Wang DH, Pham TH, Spechler SJ and Souza RF: In oesophageal squamous cells exposed to acidic bile salt medium, omeprazole inhibits IL-8 expression through effects on nuclear factor $-\kappa \mathrm{B}$ and activator protein-1. Gut 63: 1042-1052, 2014

12. Teng XJ, Liu R, Li XJ, He JF and Xiao SS: Increased expression of endothelin-1 and endothelin receptor A in reflux esophagitis and Barrett's esophagus. Dis Esophagus 26: 668-673, 2013.

13. Isomoto $\mathrm{H}$, Inoue $\mathrm{K}$ and Kohno S: Interleukin-8 levels in esophageal mucosa and long-term clinical outcome of patients with reflux esophagitis. Scand J Gastroenterol 42: 410-411, 2007.

14. Nishimura K, Tanaka T, Tsubuku T, Matono S, Nagano T, Murata K, Aoyama Y, Yanagawa T, Shirouzu K and Fujita H: Reflux esophagitis after esophagectomy: Impact of duodenogastroesophageal reflux. Dis Esophagus 25: 381-385, 2012.

15. Chen J, Hou N, Zhang C, Teng Y, Cheng X, Li Z, Ren J, Zeng J, Li R, Wang W, et al: Smooth muscle Hgs deficiency leads to impaired esophageal motility. Int J Biol Sci 11: 794-802, 2015.

16. Majka J, Rembiasz K, Migaczewski M, Budzynski A, PtakBelowska A, Pabianczyk R, Urbanczyk K, Zub-Pokrowiecka A, Matlok $\mathrm{M}$ and Brzozowski T: Cyclooxygenase-2 (COX-2) is the key event in pathophysiology of Barrett's esophagus. Lesson from experimental animal model and human subjects. J Physiol Pharmacol 61: 409-418, 2010.

17. Thomas AD, Su KY, Chang JC, Leung JH, Lee SM, Holzknecht ZE, Everett ML, Parker W, Davis RD and Lin SS: Gastroesophageal reflux-associated aspiration alters the immune response in asthma. Surg Endosc 24: 1066-1074, 2010.

18. Kassim SK, El Touny M, El Guinaidy M, El Moghni MA and El Mohsen AA: Serum nitrates and vasoactive intestinal peptide in patients with gastroesophageal reflux disease. Clin Biochem 35: 641-646, 2002.

19. Suter M, Dorta G, Giusti V and Calmes JM: Gastro-esophageal reflux and esophageal motility disorders in morbidly obese patients. Obes Surg 14: 959-966, 2004.

20. Perdikis G, Wilson P, Hinder RA, Redmond EJ, Wetscher GJ, Saeki S and Adrian TE: Gastroesophageal reflux disease is associated with enteric hormone abnormalities. Am J Surg 167: 186-191, discussion 191-192, 1994.
This work is licensed under a Creative Commons Attribution-NonCommercial-NoDerivatives 4.0 International (CC BY-NC-ND 4.0) License. 